\title{
Concerning the Mechanism of Fever
}

\author{
By G. O. SchlÜtz'1), J. VenUlet²) and E. E. BitTAR ${ }^{3}$ ) \\ From the Center of Research, University of Damascus, Damascus, Syria (Director: Professor Dr. med. G. O. Scblïtz)
}

(Eingegangen am 10. Oktober 1964)

\begin{abstract}
Experiments are described which indicate a relationship in rabbits between the activity of succinic dehydrogenase in liver cell mitochondria and the activity of the $E$. Coli pyrogen. Succinic dehydrogenase of undamaged and damaged liver tissue was measured by the method of SLATER and BONNER involving blockage of the respiratory chain with cyanide. Experiments with central and peripheral stimulators of metabolism were also tried: these suggest that pyrogen acts peripherally.

The use of pyrogen as a liver test to distinguish between the various forms of liver disease is implied by the fact that patients with hepatitis show a less intense response to $E$. Coli pyrogen than cirrhotics. Why the cirrhotic shows an increased response when compared to normal human subjects remains still unknown, but this might be related to succinic dehydrogenase activity.

Es werden Experimente beschrieben, die bei Kaninchen auf einen Zusammenhang der Fieberwirkung des Lipopolysaccharids von E. Coli mit der mitochondrialen Bernsteinsäuredehydrogenaseaktivität der Leberzellen hinweisen. Die Bernsteinsäuredehydrogenaseaktivität wurde in normalem wie auch in mit Tetrachlorkohlenstoff geschädigtem Lebergewebe nach der Methode von SLATER und BonNer unter Ausschaltung der Atmungskette mit Cyanid bestimmt. Femer wurden Versuche mit zentral und peripher wirkenden Stoffwechselstimulatoren durchgeführt. Alle diese Experimente legen nahe, daß die Fiebergenese nicht nur zentralen sondern auch großenteils peripberen Ursprungs ist: nämlich mindestens zu einem gewissen Anteil auf der Aktivierung der mitochondrialen Leberzellenbernsteinsäuredehydrogenase unter der Einwirkung von Pyrogenen beruht.

Weiter wurde das E. Coli - Pyrogen als Testsubstanz zur diagnostischen Differenzierung der verschiedenen Formen der menschlichen Lebererkrankungen benutzt, und zwar mit dem Erfolg, daß die Infekthepatitiden keine, oder eine nur sehr geringe Temperaturerhöhung auf die intravenöse $E$. Coli-Pyrogenzufuhr aufweisen, wogegen die Patienten mit Leberzirrhose mit einem bedeutend höheren Temperaturanstieg reagieren als lebergesunde Versuchspersonen. Eine Begründung hierfür kann vorläufig nicht gegeben werden, jedoch könnte dieses Phänomen vielleicht mit der Bestimmung der mitochondrialen Leberzellenbernsteinsäuredehydrogenase in Verbindung mit den zirrhotischen Vorgängen aufgeklärt werden.
\end{abstract}

Little is known so far about the mechanism of fever (1). The present paper aims to consider some experimental data dealing with the peripheral action of pyrogen.

It has long been recognized that body temperature involves the relationship of heat produced by the body to the heat lost. This thermal equilibrium is manifested by the relative constancy of body temperature generally. The centers responsible for equilibrium are located in the hypothalamus and brain stem. Under ordinary conditions heat loss is regulated by peripheral reflex action which mediates cutaneous vasodilatation or constriction, and by sweating. The response of the body to hypothermia is marked by a shaking chill or by shivering. Fever, in other words, implies thermal disequilibrium. This could be produced by a decrease in the rate of heat lost, or by an increase in the rate of heat produced. Both of these events could of course take place simultaneously.

The part played by the central mechanism in fever production by bacterial endotoxins is well recognized. Bacterial endotoxins have been shown to affect the thermostatic center in the hypothalamus. The clinical fact remains that some tumors, liver disease and negative water balance, among others, are associated with the presence of fever. The factor most common to these conditions is tissue injury. This is why the products of

\footnotetext{
1) Paper red in part at the autumn meeting of the „German Biochemical Society", Cologne, October 22/24, 1964.

2) Permanent address: Drug Research Institute, Warszawa 36, Poland.

${ }^{3}$ ) Permanent address: Department of Zoology, University of Bristol, England.
}

tissue injury such as the endogenous pyrogen found in polymorphonuclear leucocytes has been considered as responsible for the pyrogen effect. In the case of bacterial endotoxin effect, the thermostat in the hypothalamus may be set at a higher level than normal. Thus heat loss by the body is restricted. As suggested by SIEDEK et al. (2) and EICHENBERger et al. (3) the rise in basal metabolic rate might precede the rise in body temperature. This could be due to a direct effect on the thermostatic center.

One of the earlier observations of BeEson (4) was that fever produced by pyrogen is accompanied by hyperglycemia. This prompted VeNULET and co-workers $(5-8)$ to investigate the effect of pyrogen in rabbits by the use of lipopolysaccharide isolated from $E$. Coli. The hyperglycemic effect was confirmed as indicated in Table 1. Furthermore, the observation was made that blood lactic acid was appreciably diminished. Though there may be several causes for these two effects, the thing in common is an increase in liver metabolism or skeletal muscle metabolism or an increase in the metabolism of both types of tissue.

Tab. 1

Blood glucose and lactic acid levels in rabbits following use of pyrogen

\begin{tabular}{|c|c|c|c|c|}
\hline $\begin{array}{l}\text { Substances } \\
\text { measured }\end{array}$ & $\begin{array}{l}\text { Numb. of } \\
\text { animals }\end{array}$ & $\begin{array}{l}\text { Concen } \\
\text { before }\end{array}$ & $\begin{array}{l}\text { atrations } \\
\text { after pyrogen }\end{array}$ & $\mathbf{p}$ \\
\hline $\begin{array}{l}\text { Glucose in } \mathrm{mg} \% \\
\text { Lactic acid in } \mathrm{mg} \%\end{array}$ & $\begin{array}{l}30 \\
30\end{array}$ & $\begin{array}{l}93,6 \pm 8,9 \\
42,9 \pm 4,2\end{array}$ & $\begin{array}{r}120 \pm 9,7 \\
25 \pm 3,3\end{array}$ & $\begin{array}{l}\mathrm{p}<0,02 \\
\mathrm{p}<0,02\end{array}$ \\
\hline
\end{tabular}


Tab. 2

The effect of pyrogen on oxygen consumption of liver and renal slices

\begin{tabular}{|c|c|c|c|c|c|c|c|}
\hline Nr. & $\begin{array}{c}\text { Kind of } \\
\text { investigation }\end{array}$ & $\begin{array}{c}\text { Numb. } \\
\text { of } \\
\text { exp. }\end{array}$ & $\begin{array}{l}\quad \text { Liver } \\
\mathrm{O}_{2} \text { uptake in } \\
\text { microlitres } \\
\text { by } 1 \mathrm{mg} \text { of dry } \\
\text { tissue in } 2 \text { hours }\end{array}$ & $\mathbf{P}$ & $\begin{array}{c}\text { Numb: } \\
\text { of } \\
\text { exp. }\end{array}$ & $\begin{array}{l}\text { Kidney } \\
\mathrm{O}_{2} \text { uptake in } \\
\text { microlitres } \\
\text { by } 1 \mathrm{mg} \text { of dry } \\
\text { tissue in } 2 \text { hours }\end{array}$ & $\mathbf{P}$ \\
\hline 1 & Control with Ringer & 24 & $1,59 \pm 0,07$ & & 20 & $6,19 \pm 0,17$ & \\
\hline 2 & Control with serum & 24 & $1,82 \pm 0,08$ & $P_{1}=0,0891$ & 25 & $7,24 \pm 0,12$ & $P_{1}<0,0001$ \\
\hline 3 & $2 \mathrm{ng}$ pyrogen in $0,9 \% \mathrm{NaCl}$ & 31 & $1,50 \pm 0,10$ & $P_{1}=0,4237$ & 43 & $4,41 \pm 0,15$ & $\mathrm{P}_{1}<0,0001$ \\
\hline 4 & $2 \mathrm{ng}$ pyrogen incubated with serum & 20 & $2,18 \pm 0,11$ & $\begin{array}{l}\mathrm{P}_{1}<0,0001 \\
\mathrm{P}_{2}=0,0069\end{array}$ & 48 & $6,02 \pm 0,22$ & $\begin{array}{l}\mathrm{P}_{1}<0,5454 \\
\mathrm{P}_{2}<0,0001\end{array}$ \\
\hline 5 & $0,2 \mathrm{ng}$ pyrogen incubated with serum & 21 & $2,07 \pm 0,09$ & $\begin{array}{l}\mathrm{P}_{1}<0,0001 \\
\mathrm{P}_{2}=0,0377\end{array}$ & & & \\
\hline 6 & $0,02 \mathrm{ng}$ pyrogen incubated with serum & 21 & $2,17 \pm 0,10$ & $\begin{array}{l}\mathrm{P}_{1}<0,0002 \\
\mathrm{P}_{2}=0,0069\end{array}$ & & & \\
\hline 7 & $0,002 \mathrm{ng}$ pyrogen incubated with serum & 22 & $2,21 \pm 0,05$ & $\begin{array}{l}P_{1}<0,0001 \\
P_{2}=0,0001\end{array}$ & & & \\
\hline 8 & From a rabbit killed at the peak temperature & 32 & $2,55 \pm 0,05$ & $P_{1}<0,0001$ & 60 & $5, \underline{21} \pm 0,16$ & $P_{1} \pm 0,0001$ \\
\hline
\end{tabular}

Tab. 3

The effect of pyrogen on the activity of succinic acid dehydrogenase

\begin{tabular}{|c|c|c|c|}
\hline Substrate & $\begin{array}{l}\text { Number } \\
\text { of } \\
\text { experiments }\end{array}$ & $\begin{array}{l}\mathrm{O}_{2} \text { consumption in microlitres } \\
\text { by } 1 \mathrm{mg} \text { of dry mass of } \\
\text { mitochondria during } 2 \text { hours }\end{array}$ & $\mathbf{P}$ \\
\hline Mitochondria & 35 & $88,2 \pm 2,96$ & \\
\hline Mitochondria with incubated serum & 31 & $114,8 \pm 3,06$ & $P_{1}<0,001$ \\
\hline Mitochondria with $2 \mathrm{ng}$ incubated pyrogen & 26 & $167,2 \pm 3,20$ & $\begin{array}{l}\mathrm{P}_{1}<0,001 \\
\mathrm{P}_{3}<0,001\end{array}$ \\
\hline Mitochondria with $0,002 \mathrm{ng}$ incubated pyrogen & 24 & $230,4 \pm 11,29$ & $\begin{array}{l}\mathrm{P}_{1}<0,001 \\
\mathrm{P}_{2}<0,001\end{array}$ \\
\hline Mitochondria from a rabbit killed at the peak temperature & 37 & $120,4 \pm 3,22$ & $\mathrm{P}_{1}<0,001$ \\
\hline Mitochondria with $0,002 \mathrm{ng}$ incubated pyrogen and sodium malonat & ate 20 & $14,7 \pm 1,95$ & $\mathrm{P}_{4}<0,000001$ \\
\hline
\end{tabular}

As a first step, then, the $\mathrm{O}_{2}$ consumption of liver and kidney slices taken from rabbits, was measured after the animals had been injected with pyrogen. The data gathered in Table 2 shows a significant rise in $\mathrm{O}_{2}$ consumption of liver tissue. It should be noted that the amount of pyrogen with which tissue slices were treated directly was $2 \mathrm{ng}$, which is a quantity equal to that injected intravenously into the rabbits. The salient point of theses experiments is that the rise in $\mathrm{O}_{2}$ consumption occurs when the pyrogen is incubated with the homologous serum. This means that rabbit serum contains an endogenous factor which activates the pyrogen. In man, however, the endogenous pyrogen is located in the polymorphonuclear leucocyte. - The objection may be raised that the dosage of $2 \mathrm{ng}$ is disproportionately large when used on $100 \mathrm{mg}$ liver slices. Therefore, experiments in which this was gradually lessened were carried out. Even a dose of 0,002 $\mathrm{ng}$ which corresponds to $0,02 \mathrm{ng} / \mathrm{kg}$ of body weight exerted . a full effect. In these experiments rabbits sacrificed at peak temperature demonstrated an increase in liver $\mathrm{O}_{2}$ consumption. Kidney tissue, however, showed the opposite effect: a decrease in $\mathrm{O}_{2}$ consumption, the most pronounced effect occuring at peak temperature also. Using the same dosage scale, other issues of the body such as brain and muscle failed to show a similar pyrogen effect.
The next step was to localize the sub-cellular site of pyrogen action. The following sub-cellular fractions taken from liver homogenates were studied: nuclei, mitochondria, and microsomes with endoplasmic fluid. No increments in oxygen consumption in any of the fractions treated with pyrogen were observed. One explanation for this was the lack of substrates; another was the "dispersion effect" (Trennungseffekt) resulting from the differential centrifugation and in vitro nature of the experiments. At any rate, experiments were tried with two enzyme systems, viz. succinic dehydrogenase and lactic dehydrogenase. The activity of succinic dehydrogenase in mitochondria was measured by the manometric method of SLATER and BonNER (9). The method involves blocking the cytochrome system by cyanide and the acceptance of free $\mathrm{H}_{2}$ by methylene blue. Inhibition of succinic dehydrogenase by malonic acid insured the specificity of the $\mathrm{H}_{2}$ transfer.

Table 3 shows a rise in mitochondrial succinic dehydrogenase activity after the treatement with small amounts of pyrogen. Rabbits sacrificed at peak temperature show a significant but less pronounced rise in succinic dehydrogenase activity. Lactic dehydrogenase activity which was measured by the method of GrEeN and Brosteaux (10) showed no change. - The inference, then, is that a relationship exists between the liver and pyrogen, or more specifically, between mitochondrial 
succinic dehydrogenase activity and the pyrogen effect. Rowley (11) is known to have shown a selective accumulation of pyrogen material in the liver by using a ${ }^{32} \mathrm{P}$-technique. This may well be interpreted to merely mean an increase in reticulo-endothelial activity.

What happens to the pyrogen effect when the liver is damaged? Because about $6 \%$ of rabbits are resistant to pyrogen, only those exhibiting an effect were injected subcutaneously with $\mathrm{CCl}_{4}$, the dosage being $1,5 \mathrm{~m} / \mathrm{kg}$ body weight. Liver dysfunction became maximal at about the third day. This is indicated by rises in blood beta-globulines, SGOT and SGPT. There is also retention of Bromsulphalein. The galactose test stays normal, however. Figure 1 provides the febrile course provoked by weekly intravenous injections of pyrogen together with the liver function profile. The

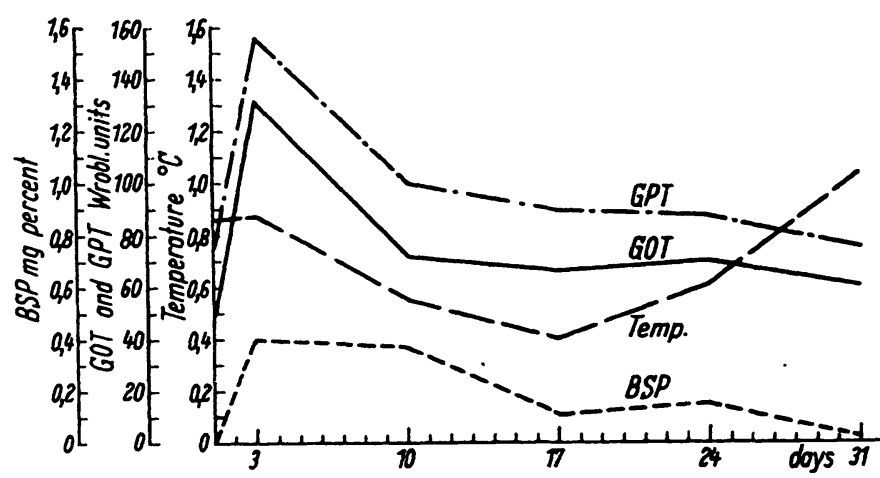

Fig. 1

The correlation between liver function and pyrogenic activity recorded curve is typical: about the 10 th to 17 th day following $\mathrm{CCl}_{4}$-treatment the pyrogen response decreases only to reappear gradually during the recovery period. Although the evidence here suggests a peripheral mechanism for the pathogenesis of fever, the dissociation in time between peak damage and blunting of the pyrogen effect is an unexplained observation. Of course, it might be reasoned that if the pyrogen activator is produced by the liver and liberated into the circulation there might be enough of it, even a few days after effecting liver damage, to combine with pyrogen.

In view of the fact that liver damage leads to blunting of the pyrogen effect, the question arises wether a similar effect occurs following the use of a peripheral or central stimulator of metabolism, such as 2,4-dinitrophenol (DNP) and lysergic acid diethylamide (LSD), respectively. The former is known to act by uncoupling oxidative phosphorylation in liver and muscle. The data collected in Table 4 shows that the LSD effect lasts through the experiment and is independent of the severity of liver damage. But not so with DNP. The hyperthermia is temporarily abolished and is restored when liver function improves. These differences in activity were described by STAEChELIN and TAESCHLER (12) but not explained in terms of a peripheral mechanism. In regard to $\mathrm{O}_{2}$ consumption measurements, liver slices show increments with DNP treatment and no change with SLD. This data is recorded in Table 5. Now liver slices taken from rabbits treated with $\mathrm{CCl}_{4}$ reveal a significant decrease in $\mathrm{O}_{2}$ consumption. Table 6

Tab. 4

The influence of different pyretogenic drugs on body temperature of rabbits with $\mathrm{CCl}_{4}$ liver damage

\begin{tabular}{|c|c|c|c|c|c|c|c|c|}
\hline Drug and dose & $\begin{array}{c}\text { Numb. of } \\
\text { experiments }\end{array}$ & $\begin{array}{l}\Delta t^{\circ} \text { before } \\
\text { damage }\end{array}$ & 4 & $\begin{array}{c}\Delta t^{\circ} \text { aft } \\
11\end{array}$ & $\begin{array}{l}\mathrm{ge} / \mathrm{CC} \\
18\end{array}$ & 25 & 32 day & $\begin{array}{c}t^{\circ} \text { Sr with } \\
\text { P } 0,95\end{array}$ \\
\hline Pyrogen $0,02 \mu \mathrm{g} / \mathrm{kg}$ & 38 & 0,85 & 0,85 & 0,55 & 0,41 & 0,59 & 1,0 & 0,2 \\
\hline $\mathrm{LSD} 5 \mu \mathrm{g} / \mathrm{kg}$ & 20 & 0,71 & 0,82 & 0,80 & 0,86 & 0,85 & 0,80 & 0,15 \\
\hline 2,4-dinitrophenol $10 \mathrm{mg}$ & 20 & 0,97 & 1,10 & 0,52 & 0,51 & 0,60 & 0,80 & 0,23 \\
\hline
\end{tabular}

Tab. 5

The effects of LSD and DNP on oxygen consumption of liver slices from normal and $\mathrm{CCl}_{4}$ damaged livers

\begin{tabular}{|c|c|c|c|c|c|c|c|}
\hline Nr. & $\begin{array}{c}\text { Kind of } \\
\text { investigation }\end{array}$ & \multicolumn{2}{|c|}{$\begin{array}{c}\text { Normal liver } \\
\mathrm{O}_{2} \text { uptake in } \\
\text { Numb. microlitres } \\
\text { of by } 1 \mathrm{mg} \text { of dry } \\
\text { exp. tissue in } 2 \text { hours }\end{array}$} & $\mathbf{P}$ & $\begin{array}{l}\text { CC } \\
\text { Numb. } \\
\text { of } \\
\text { exp. }\end{array}$ & $\begin{array}{l}\mathrm{Cl}_{4} \text { damaged li } \\
\mathrm{O}_{2} \text { uptake in } \\
\text { microlitres } \\
\text { by } 1 \mathrm{mg} \text { of dry } \\
\text { tissue in } 2 \text { hours }\end{array}$ & ver \\
\hline 1 & Control with Ringer & 96 & $1,61 \pm 0,04$ & & 74 & $1,22 \pm 0,04$ & \\
\hline 2 & Control with serum & 24 & $1,82 \pm 0,08$ & & 28 & $1,25 \pm 0,08$ & \\
\hline 3 & $\mathrm{LSD} 0,5 \mu \mathrm{g}$ in Ringer & 19 & $1,66 \pm 0,09$ & $\mathrm{P}_{r}<0,4$ & 28 & $1,33 \pm 0,07$ & $P_{r}<0,4$ \\
\hline 4 & LSD $0,5 \mu \mathrm{g}$ incubated with serum & 33 & $1,75 \pm 0,06$ & $\mathrm{P}_{8}<0,48$ & 28 & $1,39 \pm 0,07$ & $P_{s}<0,32$ \\
\hline 5 & From a rabbit killed at the peak temperature & 20 & $1,60 \pm 0,08$ & $P_{r}<0,4$ & 20 & $1,25 \pm 0,05$ & $P_{8}<0,41$ \\
\hline 6 & Control with Ringer & 96 & $1,61 \pm 0,04$ & & 74 & $1,22 \pm 0,04$ & \\
\hline 7 & Control with serum & 30 & $1,85 \pm 0,07$ & $P_{r}=0,01$ & 25 & $1,27 \pm 0,09$ & $P_{r}<0,22$ \\
\hline 8 & DNP $1 \mathrm{mg}$ in Ringer & 33 & $1,93 \pm 0,11$ & $P_{r}=0,001$ & 24 & $0,97 \pm 0,05$ & \\
\hline 9 & DNP $1 \mathrm{mg}$ incubated with serum & 30 & $2,16 \pm 0,08$ & $P_{s}=0,001$ & 24 & $1,10 \pm 0,05$ & $P_{s}<0,3$ \\
\hline 10 & From a rabbit killed at the peak temperature & 23 & $1,91 \pm 0,08$ & $\mathrm{P}_{r}=0,001$ & 20 & $1,18 \pm 0,08$ & $\mathrm{P}_{r}<0,4$ \\
\hline
\end{tabular}


Tab. 6

The effect of pyrogen on oxygen consumption of liver slices from normal and $\mathrm{CCl}_{4}$ damaged livers

\begin{tabular}{|c|c|c|c|c|c|c|c|}
\hline \multirow[b]{2}{*}{ Nr. } & \multirow[b]{2}{*}{$\begin{array}{c}\text { Kind of } \\
\text { investigation }\end{array}$} & \multicolumn{3}{|c|}{ Normal liver } & \multicolumn{3}{|c|}{$\mathrm{CCl}_{4}$ damaged liver } \\
\hline & & $\begin{array}{c}\text { Numb. } \\
\text { of } \\
\text { exp. }\end{array}$ & $\begin{array}{l}\mathrm{O}_{2} \text { uptake in } \\
\text { microlitres } \\
\text { by } 1 \mathrm{mg} \text { of dry } \\
\text { tissue in } 2 \text { hours }\end{array}$ & $\mathbf{P}$ & $\begin{array}{c}\text { Numb. } \\
\text { of } \\
\text { exp. }\end{array}$ & $\begin{array}{l}\mathrm{O}_{2} \text { uptake in } \\
\text { microlitres } \\
\text { by } 1 \mathrm{mg} \text { of dry } \\
\text { tissue in } 2 \text { hours }\end{array}$ & $\mathbf{P}$ \\
\hline 1 & Control with Ringer & 96 & $1,61 \pm 0,04$ & & 74 & $1,22 \pm 0,04$ & \\
\hline 2 & Control with serum & 24 & $1,82 \pm 0,08$ & & 28 & $1,25 \pm 0,08$ & \\
\hline 3 & 2 ng pyrogen in Ringer & 31 & $1,50 \pm 0,10$ & & 27 & $1,21 \pm 0,06$ & \\
\hline 4 & $2 \mathrm{ng}$ pyrogen incubated with serum & 20 & $2,18 \pm 0,11$ & $P_{s}=0,01$ & 28 & $1,18 \pm 0,07$ & $\mathrm{P}_{s}<0,58$ \\
\hline 5 & From a rabbit killed at the peak temperature & 32 & $2,55 \pm 0,05$ & $\mathrm{P}_{r}=0,001$ & 40 & $1,58 \pm 0,06$ & $\mathrm{P}_{r}=0,001$ \\
\hline
\end{tabular}

Tab. 7

Average temperature rise in three groups of human subjects secondary to $1 \mu \mathrm{g}$ of lipopolysaccharide given intravenously

\begin{tabular}{|c|c|c|c|c|c|c|c|c|c|c|c|}
\hline \multicolumn{4}{|c|}{ Control } & \multicolumn{4}{|c|}{ Other liver diseases } & \multicolumn{4}{|c|}{ Inf. Hepatitis } \\
\hline Nr. & $\Delta t^{\circ}$ & SGOT & SGPT & Nr. & $\Delta t^{\circ}$ & SGOT & SGPT & Nr. & $\Delta t^{\circ}$ & SGOT & SGPT \\
\hline 1 & 1,5 & 17 & 0 & 11 & 2,1 & 37 & 18 & 22 & 1,8 & 175 & 316 \\
\hline 2 & 1,4 & 25 & 15 & 12 & 1,2 & $18 \overline{7}$ & 296 & 23 & 1,0 & & 1820 \\
\hline 3 & 1,3 & 25 & 18 & 13 & 1,5 & 112 & 107 & 24 & 1,3 & 152 & 350 \\
\hline 4 & 0,9 & 30 & 8 & 14 & 1,8 & 32 & 16 & 25 & 0,7 & 25 & 176 \\
\hline 5 & 2,2 & 90 & 3 & 15 & 1,5 & 67 & 36 & 26 & 2,2 & 175 & 870 \\
\hline 6 & 1,1 & 32 & 21 & 16 & 1,9 & 67 & 32 & 27 & 0,4 & 150 & 242 \\
\hline 7 & 1,6 & 4 & 10 & 17 & 1,7 & 75 & 57 & 28 & 0,7 & 75 & 100 \\
\hline 8 & 1,8 & 30 & 29 & 18 & 2,1 & 61 & 42 & 29 & 0,5 & 155 & 230 \\
\hline 9 & 1,5 & 37 & 25 & 19 & 2,5 & 92 & 30 & 30 & 1,2 & 135 & 135 \\
\hline \multirow[t]{2}{*}{10} & 1,2 & 42 & 25 & 20 & 1,7 & 75 & 45 & 31 & 1,0 & 75 & 111 \\
\hline & & & & 21 & 2,4 & 112 & 100 & 32 & 0,5 & 12 & 117 \\
\hline verage & 1,45 & 26 & 15 & & 1,85 & 82 & 70 & & 1,03 & 102 & 397 \\
\hline
\end{tabular}

indicates this. Neither pyrogen nor DNP in concentrations used with undamaged liver give rise to increments in $\mathrm{O}_{2}$ consumption. By contrast, rabbits treated with $\mathrm{CCl}_{4}$ when sacrificed at the peak of DPN-induced hyperthermia show a definite rise in $\mathrm{O}_{2}$ consumption. Table 5 bears this out.

With the above information in hand, three groups of people were studied: the normal subject, the cirrhotic and the hepatitic (13). Granted that the $\mathrm{CCl}_{4}$ damaged liver differs from the cirrhotic and hepatitic liver, the purpose of such an investigation was to test the idea (and prediction) that the pyrogen response in the patient with hepatitis would be less intense than in the cirrhotic and normal human subject. Table 7 shows our results. In the ten normal subjects the mean temperature rise was $1,45^{\circ}$, in the eleven cirrhotics $1,85^{\circ}$ and in the eleven hepatitics (in the early convalescent stage) $1,03^{\circ}$. It would seem as if blunting of the pyrogen effect in hepatitics might be associated with a decrease in succinic dehydrogenase activity. - One of our future tasks then, is to measure the activity of this enzyme in $\mathrm{CCl}_{4}$ damaged livers and in the livers of patients with hepatitis.

\section{References}

1. Wood JR., W. B., Amer. J. Med. 13, 351 (1955). - 2. SiedeK, H. and H. Hausler, Dtsch. med. Wschr., 80, 1128 (1955). - 3. Eichenderger, E., M. Schmidhauser-Kopp, H. HuRni, M. FrICSAY and O. Westphal, Schweiz. med. Wschr., 85, 1211 (1955). - 4. BeEson, P. B., J. Exper. Med., 86, 29 (1947). 5. Desperak-Naciazek, A. and J. Venulet, Acta physiol. polon., 11, 623 (1960). - 6. Desperak-Naciazek, A. and J. Venulet, Unpublished results. - 7. VenULET, J. and A. DesperaK-NACIAZEK, Experientia (Basel) 13, 365 (1957). - 8. VEnulet, J. and A.
Desperak-Nactazek, Arch. int. Pharmacodynam. Thérap. 144, 465 (1963), - 9. Slater, E. C. and W. D. Bonner, Biochem. J. 52, 185 (1952). - 10. GreEN, D. E. and J. Brosteaux, Biochem. J. 30, 1489 (1936). - 11. Rowtey, D., J. Exper. Path. 37, 223 (1956). - 12. Staechelin, H. and M. Taeschler, Helv. physiol. pharmacol. Acta 23, 17 (1959). - 13. Schlütz, G. O., J. Venulet and E. E. Bitrar, (Abstract V/145) Sixth Int. Congress of Biochemistry, New York, August 1964.

Professor Dr. med. G. O. Schlütz Center of Research, University of Damascus Damascus, Syria

Permanent address:

Med.-Chem. Laboratorium Dr. Schlütz 78 Freiburg i. Br. 